\title{
28 Research Square \\ Plastic pollution in the aquatic ecosystem: an emerging threat need to be tackled
}

\section{Mir Mohammad Ali}

Sher-e-Bangla Agricultural University

\section{Paola Reale}

WorldFish

\section{Md. Saiful Islam}

PSTU: Patuakhali Science and Technology University

\section{Md Asaduzzaman}

Chattogram Veterinary and Animal Sciences University

\section{Mahbub Alam}

Bangladesh University of Professionals

Md. Mostafizur Rahman ( $\sim$ rahmanmm@juniv.edu )

Hokkaido University, Japan https://orcid.org/0000-0002-5290-3821

\section{Research Article}

Keywords: Ecotoxicology, Litter, Microplastics, Polymers, Pollution, Toxicity

Posted Date: July 14th, 2021

DOl: https://doi.org/10.21203/rs.3.rs-706099/v1

License: (c) (i) This work is licensed under a Creative Commons Attribution 4.0 International License. Read Full License 


\section{Abstract}

The accumulation of plastic substances in the aquatic ecosystem is a threat that should not be underestimated. Smaller plastic pieces, such as microplastics and nanoplastics, are of particular concern since their presence in the food web is persistent. Microplastics enter in the food chain and its very bottom, when aquatic organisms eat or ingest contaminated food materials, and keep being transferred in the next food web such as predators including humans. It is evident that aquatic organisms frequently ingest microplastics across a variety of feeding guilds. Marine organisms may cause shock, inner or outer injuries, ulcerating sores, blocking digestive tracts, fake feelings, degraded feeding capabilities, fatigue, weakness, limited predator prevention, or death due to the ingestion of large plastic material and/or particles. However, effects of microplastic particles on marine organisms and the toxicity mechanisms are largely unknown. There is much more limited evidence of the impacts of microplastics intake on freshwater species, both in the limited number of studies performed and the number of species examined. However, a few recent freshwater investigations imply that the physical impacts are similar to those observed in the sea. As a result, we conducted a brief evaluation of the state of the science in order to identify knowledge gaps and research requirements to examine the impacts of microplastics on aquatic ecosystem. To yet, just a few researches have looked at the biological consequences of plastics on aquatic organisms, and the important transport pathways of plastics from freshwater to marine environments and vice-versa.

\section{Introduction}

Plastic pollution has been a global environmental problem with the spread and impacts of plastic debris on the aquatic biota, biodiversity and human health in all aquatic environments worldwide (Lares et al., 2018; Li et al., 2018; Beaumont et al., 2019; Blettler and Wantzen, 2019; Du et al., 2020; Haram et al., 2020; Li et al., 2020; Mataji et al., 2020; Scherer et al., 2020; Zhang et al., 2020a). Plastic products have globally used rapidly because of its exceptional features as light-weight, versatile, durable and low-cost production (GESAMP, 2015; Ballent et al., 2016; Ivleva et al., 2017; Hahladakis et al., 2018; Shafiq et al., 2019; Capolupo et al., 2020; Parata et al., 2020). In the 1950s, global plastics production was estimated around 1.5 million tons per year whereas in 2007 it was assessed nearly 250 million tons per year (PlasticEurope, 2008). With the increasing of annual global production of plastics, in 2016 it was also calculated around 322 million tones and that is still increasing by $10 \%$ each year (PlasticEurope, 2016; Crew et al., 2020). Consequently, these materials significantly contribute to the generation of waste (Stoiev and Turra, 2016; Saeed et al., 2020) and annually, between 5 and 13 million tons are estimated to leak into the world's oceans (World Economic Forum, 2016; Xu et al., 2020).

In the today's society, the plastics are therefore universal and plastic pollution is a defining human legacy on earth (Vince and Hardesty, 2017; Rochman, 2018; Alves and Figueiredo, 2019; Ma et al., 2020).

Because of the increasing production of plastic products and extensive usage, a significant portion of the plastics enters and persists in aquatic ecosystems through many routes such as plastic litter (Dris et al., 2015; Gasperi et al., 2015; Crawford and Quinn, 2017; Wang et al., 2020a) and, finally reach the oceans 
via rivers (BKV, 2017; Koelmans et al., 2014; Goswami et al., 2020) owing to their durability, low-recycling rates and poor waste management (Cole et al., 2011; Rochman, 2015; Lebreton et al., 2017; Egessa et al., 2020). There, UV radiation, biological degradation, mechanical abrasion and disintegration affect the plastic litter to produce tiny plastic fragments (Browne et al., 2011; Cole et al., 2011; Gall and Thompson, 2015; Song et al., 2017; Pathak and Navneet, 2017; Qi et al., 2020; Wang et al., 2020b).

Plastic wastes are in water mainly as mega- $(>1 \mathrm{~m})$, macro- $(<1 \mathrm{~m})$, meso- $(<2.5 \mathrm{~cm})$ or microplastic $(<5$ $\mathrm{mm})$; in sediments as micro \& meso-plastic; in aquatic organisms as micro and nano $(<0.1 \mu \mathrm{m})$ plastic (Cheshire et al., 2009; Browne et al., 2015; Lusher et al., 2017a; Chatterjee and Sharma, 2019; Liu et al., 2020a; Uddin et al., 2020), recognized as an emerging threat, as well as ecotoxicological and ecological risk for aquatic ecosystems. As the plastic breaks into smaller pieces, its infiltration of food webs as microplastics are more common (Browne et al., 2008; Rochman, 2015; Li et al., 2020). Smaller plastics can readily be swallowed by aquatic fish and invertebrates, causing stress, disruption of feeding, damage, metabolic function changes, and tumor growth, according to studies. (Rosenkranz et al., 2009; Imhof et al., 2013; Sanchez et al., 2014; Biginagwa et al., 2016; Rochman, 2016; Koongolla et al., 2020; Liu et al., 2020b; Yu et al., 2020). Furthermore, most plastics are chemically toxic and serve as a pollutant sink (Teuten et al., 2009; Rochman et al., 2013a; Vandermeersch et al., 2017; Du et al., 2020; Robin et al., 2020; Walkinshaw et al., 2020).

Despite extensive research efforts investigating plastic contamination (microplastic only, very few of them reported mega-, macro-, meso-, micro- and nano plastics and all size ranges with its pattern, distribution, source, color, shape \& size) round the world in marine water, surface or beach sediment and in terrestrial organisms (Eriksen et al., 2013; Imhof et al., 2013; Wright et al., 2013; Ivar do Sul and Costa, 2014; Noik and Tuah, 2015; Biginagwa et al., 2016; Pereao et al., 2020), few studies have been focused on freshwater aquatic ecosystems (Morritt et al., 2014; Wagner et al., 2014; Klein et al. 2015; Zhang et al., 2020). There is already proved that several microplastic particles and fibers can accumulate not only marine water but also freshwaters; though fewer microplastic monitoring concentrations have been done on freshwater systems than in seawaters (Klein et al., 2018; Fu and Wang, 2019; Yu et al., 2020). Thus, the knowledge about the plastic waste in river water and sediment in the world are scare, and there is still very little information on their presence, sources and destiny (Thompson et al., 2009; Eerkes-Medrano et al., 2015) along with the social campaign for proper plastic management in freshwater and marine water is very rare.

In order to better understand the plastic pollution and its potentials, this review chapter seeks at exposing the existing knowledge of plastic pollution in the aquatic ecosystem. Target-oriented plastics particle management options, abundance, distribution and rarity learning are far from sufficient and further sound research is needed (Peng et al., 2017; Wang et al., 2017; Martins et al., 2019; Masia et al., 2020). Finally, there are several key challenges and suggestions are discussed for further plastic research, and a plastic pollution reduce campaign throughout the society are highly recommended.

\section{Plastics In The Environment}




\subsection{What is plastic?}

Plastic production was started in 1950s for a large-scale basis. It was rapidly increased in response to a growing demand for produced commodities and packaging for food or the products to protect from contaminants (Koelmans et al., 2015; Chatterjee and Sharma, 2019; Li et al., 2020; Qi et al., 2020). The term "plastic" refers to a category of synthetic polymers that come in a variety of sizes depending on the purpose. It refers to many ways in various studies as mega-, macro-, meso-, micro-nano plastics (Fig. 1).

\subsection{Classification of plastics}

The classification of sizes in plastics have emerged alongside their recognition as a type of aquatic litter. Fiber processing from pre-production or melting of resin pellets produces mega- and macro-plastic goods, which have a wide range of applications ranging from garments to industrial constructions. Microplastics are used to make facewash scrubbers, cosmetic microbeads, powders, and macroplastic objects, among other things (pre-production resin pellets). Nanoscale plastics include biomedicines, pharmacological drug delivery systems and medicinal diagnostics (Koelmans et al., 2015; Uddin et al., 2020; Liu et al., 2020a).

Table 1

Description and types of different plastics in the environmental

\begin{tabular}{|c|c|}
\hline Category & Description \\
\hline Classification & $\begin{array}{l}\text { The plastics of the environment are a very heterogeneous waste group which may be } \\
\text { characterized by different descriptors. Until now, there is no specific universal } \\
\text { method for classification. It can be laminated by size, origin, form, type of polymer } \\
\text { and color [Wagner et al., 2014] }\end{array}$ \\
\hline Size & $\begin{array}{l}\text { The size groups for plastic litter as follows: megaplastics }(>1 \mathrm{~m}) \text {, macroplastics }(<1 \\
\text { m), mesoplastics }(<2.5 \mathrm{~cm}) \text {, microplastics }(<5 \mathrm{~mm}) \text {, and nanoplastics }(<0.1 \mu \mathrm{m}) \\
\text { [Lusher et al., 2017a; Chatterjee and Sharma, 2019]. }\end{array}$ \\
\hline Origin & $\begin{array}{l}\text { Microplastics can also be categorized based on their source: primary microplastics, } \\
\text { for example, are formed from resin pellets (plastic raw materials). Secondary } \\
\text { microplastics are the result of UV radiation and physical abrasion breaking down } \\
\text { bigger polymers into smaller particles [Lusher et al., 2017a]. }\end{array}$ \\
\hline Polymers & $\begin{array}{l}\text { In line with global production rates, the most common polymers used in the } \\
\text { atmosphere are polypropylene (PP), polyethylene terephthalate (PET), high-and low- } \\
\text { density polyethylene (HD / LD-PE), polystyrene (PS), and polyvinyl chloride (PVC). } \\
\text { Additionally, polyamide (nylon) fibers from fishing gears are popular [Andrady, 2011; } \\
\text { GESAMP, 2015]. }\end{array}$ \\
\hline Shape & $\begin{array}{l}\text { Fragments (irregularly formed particles, crystals, fluff, powder, granules, shavings, } \\
\text { flakes, films), fibers (filaments, microfibers, loops, threads), beads (grains, spherical } \\
\text { microbeads, microspheres), foams (polystyrene, expanded polystyrene), foams } \\
\text { (polystyrene, expanded polystyrene) and pellet (pellets of resin, nutrients, pellets of } \\
\text { pre-production) are main plastic shapes [Lusher et al., 2017b]. }\end{array}$ \\
\hline
\end{tabular}

\subsection{Environmental fate of plastics and its application}


Plastics' environmental fate is largely determined by their density (Table 2), which determines resistance, location in the water column, and subsequent potential contact with biota (Wright et al., 2013a; Yu et al., 2020). Polymers with a lower density than seawater (e.g., PP, PE) will float in the water column, but highdensity polymers (>1.027 g / cm3, PVC) will sink. Invasion of organisms and biofouling on the plastic surface increase the weight of the artifacts, causing them to sink to the bottom sediments; fragmentation, leaching, and oxidation of additives can further change the density and distribution of artifacts throughout the water column (Lobelle and Cunliffe, 2011; Du et al., 2020).

Table 2

Types of plastics, their most typical applications, their gravity that are found in the aquatic environment (Andrady, 2011, Nerland et al. 2014, PlasticsEurope 2015, GESAMP 2015)

\begin{tabular}{|c|c|c|}
\hline Plastic-type & Common applications & $\begin{array}{l}\text { Specific } \\
\text { gravity* }\end{array}$ \\
\hline Polyethylene & Plastic bags, Toys, bottles, pipes, packaging, storage containers & $\begin{array}{l}0.91- \\
0.95\end{array}$ \\
\hline Polypropylene & $\begin{array}{l}\text { Ropes, bottle caps, folders/hinges, food packaging, strapping, } \\
\text { diapers, fishing gears, furniture, wastebaskets }\end{array}$ & $\begin{array}{l}0.90- \\
0.92\end{array}$ \\
\hline $\begin{array}{l}\text { Polystyrene } \\
\text { (expanded) }\end{array}$ & Cool boxes, floats, cups & $\begin{array}{l}1.01- \\
1.05\end{array}$ \\
\hline Polystyrene & $\begin{array}{l}\text { Utensils, containers, plastic cups, cd cases, disposable razors, } \\
\text { electronic packaging }\end{array}$ & $\begin{array}{l}1.04- \\
1.09\end{array}$ \\
\hline $\begin{array}{l}\text { Polyvinyl } \\
\text { chloride }\end{array}$ & Film, pipes, containers, window frames, flooring, construction & $\begin{array}{l}1.16- \\
1.30\end{array}$ \\
\hline $\begin{array}{l}\text { Polyamide or } \\
\text { Nylon }\end{array}$ & Fishing nets, rope & $\begin{array}{l}1.13- \\
1.15\end{array}$ \\
\hline $\begin{array}{l}\text { Poly (ethylene } \\
\text { terephthalate) }\end{array}$ & $\begin{array}{l}\text { Bottles, strapping, textiles, frozen dinner packages, polyester } \\
\text { clothing }\end{array}$ & $\begin{array}{l}1.34- \\
1.39\end{array}$ \\
\hline $\begin{array}{l}\text { Polyester resin + } \\
\text { glass fiber }\end{array}$ & Textiles, boats & $>1.35$ \\
\hline Cellulose Acetate & Cigarette filters & $\begin{array}{l}1.22- \\
1.24\end{array}$ \\
\hline Pure water & & 1.000 \\
\hline Seawater & & 1.027 \\
\hline Brackish water & & $\begin{array}{l}1.005- \\
1.012\end{array}$ \\
\hline
\end{tabular}

\subsection{Sectors generating plastics}


Leisure activities, food supply, energy consumption, transportation, and housing supply are all factors that influence plastic usage, and they vary depending on the social and economic climate. This, in turn, has an impact on technological innovation, product design, market demand, waste generation, and trash disposal. Unfortunately, environmental externalities such as the social, economic, and ecological repercussions of aquatic trash have been overlooked by the business sector. (Wagner and Lambert, 2018). Due to the industrialization the plastic particles can also be accumulated in the environment through specific applications, processes or products by primary and secondary sources (Fig. 2).

The new 'plastic economy' has been defined by a linear output and use pattern, producing enormous amounts of waste, which is essentially quite economically inefficient (Defra, 2015; UNEP, 2016; Capolupo et al., 2020). Figure 3 illustrates land and water-based plastics sources, and the routes through which plastics enter the ocean.

Tracks in the land-based sector may go across rivers, through the environment, or directly into the ocean (e.g., through dropping litter on the shoreline). Maritime activities employ a variety of plastics styles for both long-term (e.g., fishing gear) and short-term (e.g., ropes) applications (e.g., packaging). Table 3 shows the potential industries involved, as well as garbage or different types of plastic products and the ocean's regular entry points. 
Table 3

Sources of plastic, waste materials, ocean entry locations, and their relative importance (GESAMP 2016; Saeed et al., 2020)

\begin{tabular}{|c|c|c|c|}
\hline Sector & Explanation & Entrance points & $\begin{array}{l}\text { Relative } \\
\text { importance* }\end{array}$ \\
\hline \multicolumn{4}{|l|}{ Land-based source } \\
\hline Retail & $\begin{array}{l}\text { Packaging, consumer goods, household } \\
\text { goods }\end{array}$ & $\begin{array}{l}\text { Rivers, coastal, } \\
\text { atmosphere }\end{array}$ & High \\
\hline Food and drink & Single-use packaging & $\begin{array}{l}\text { Rivers, coastal, } \\
\text { atmosphere }\end{array}$ & High \\
\hline Households & $\begin{array}{l}\text { Packaging, consumer goods, household } \\
\text { goods }\end{array}$ & $\begin{array}{l}\text { Rivers, coastal, } \\
\text { atmosphere }\end{array}$ & High \\
\hline Tourism industry & $\begin{array}{l}\text { Packaging, consumer goods, household } \\
\text { goods }\end{array}$ & $\begin{array}{l}\text { Rivers, coastal, } \\
\text { atmosphere }\end{array}$ & High \\
\hline Construction & EPS, packaging & $\begin{array}{l}\text { Rivers, coastal, } \\
\text { atmosphere }\end{array}$ & Medium \\
\hline Agriculture & Films/sheets, pipes, pots & $\begin{array}{l}\text { Rivers, coastal, } \\
\text { atmosphere }\end{array}$ & Low \\
\hline $\begin{array}{l}\text { Terrestrial } \\
\text { Transportation }\end{array}$ & End-of-life tires and vehicles & $\begin{array}{l}\text { Rivers, } \\
\text { shorelines }\end{array}$ & Low \\
\hline \multicolumn{4}{|l|}{ Water-based source } \\
\hline Fisheries & $\begin{array}{l}\text { Fishing gears, strapping bands, } \\
\text { packaging, storage boxes, personal goods }\end{array}$ & Coastal, Marine & High \\
\hline Aquaculture & $\begin{array}{l}\text { Buoys, nets, lines, structures, storage boxes, } \\
\text { personal goods, packaging }\end{array}$ & Coastal, Marine & Medium \\
\hline $\begin{array}{l}\text { Shipping/Offshore } \\
\text { industry }\end{array}$ & Cargo, personal goods, packaging & Coastal, Marine & Medium \\
\hline $\begin{array}{l}\text { Ship-based } \\
\text { tourism }\end{array}$ & Packaging, personal goods & Coastal, Marine & Medium \\
\hline
\end{tabular}

\section{Plastics As A Pollutant}

The environmental impact of plastics can differ based on the chemical composition of plastics. Till now, the most widely used plastics have been polyethylene (PE) and polypropylene (PP), which have been used to produce packaging materials and malleable films, as well as automobile components, fishing gear, pipelines, and kitchenware. PET is a type of polyethylene terephthalate (PET) that is extensively used in apparel and drinking cups. PVC is employed in the automotive and construction industries, and 
polystyrene (PS) is used in a variety of applications, including building insulation and packaging (Wang et al., 2020a).

Most plastic polymers are low in toxicity due to their unique properties, such as being biochemically inactive due to their high molecular weight and insolubility in water. Monomers are used to make plastic polymers, which are subsequently combined to form synthetic polymers. The majority of monomers, such as vinyl chloride or styrene, are poisonous and carcinogenic, and monomer residues in plastic goods may be dangerous (Lithner et al., 2011; Haram et al., 2020). Four plastics (PVC, PU, PS, and PC) that make up about 30 percent of global production are considered especially difficult because they often contain toxic monomers or additives (Rochman et al., 2013b). Plasticizers and fillers that modulate texture or coloring agents, flame retardants, antimicrobials, and other compounds that alter the material's qualities in beneficial ways are examples of these additions (Deanin 1975). Such compounds may endanger the health of people and other animals (Rochman, 2015; Koch and Calafat, 2009; Parata et al., 2020) and may reduce the potential for recycling and reuse. Bisphenol A (BPA), which is extensively used in the making of polycarbonate (PC) plastic water bottles and other resins used in food containers but has been subject to regulation due to its hormone-like characteristics, estrogen mimicking, and human accumulation, is one well-known example (Koch and Calafat, 2009; Egessa et al., 2020). Likewise, certain common plasticizers (adipates and phthalates) have hormone-like effects and are commonly used to smooth brittle plastics like PVC so that they can be used in food packaging, toys, and a variety of other everyday products (Koch and Calafat, 2009; Da Costa et al., 2016; Qi et al., 2020).

\section{Potential Impacts Of Plastics In The Aquatic Ecosystem 4.1 Commercially important flora and fauna}

Plastic particle ingestion by ecologically vulnerable species has now been documented in a variety of environments, including beaches, aquaculture, estuaries, sea surface, water column, and benthos (Lusher 2015; GESAMP 2016; Amoatey and Baawain, 2019; Pereao et al., 2020), and deep sea (Taylor et al., 2016). The diversity of the species investigated and the habitats from which they are taken necessitates a variety of collecting procedures (Lusher et al., 2017b). Through several studies it has been found that more than 220 different animals eat microplastic debris across nature (GESAMP, 2016; UNEP, 2016). Beyond the individual stage, assemblages, and populations, interactions with environmental variables, including pollutants, and contamination of a long-lived organism at various levels and times during ontogeny, it is also critical to understand the ecology of microplastics (flora and fauna interactions (Ferreira et al., 2016; Wang et al., 2020b).

\subsection{Marine mammals and seabirds}

Microplastics have been discovered in aquatic birds and marine mammals, and they may be of relevance to humans and the environment. Humans eat a variety of bird species, and each seabird species tested has at least one person with digestive tract microplastics (Van Franeker et al., 2011; Roman et al., 2019; Basto et al., 2020). 
Marine mammals can ingest microplastics but it is hard to determine the source of microplastic. It was detected in baleen whales, Mesoplodon mirus (Lusher et al., 2015a), beaked whales, Megaptera nevaeangliae (Besseling et al., 2015a) and seal stomachs Phoca vitulina (Bravo Rebolledo et al. 2013). For marine animals, microplastics may be produced from feeder on the aquaculture or by ingesting microplastic prey. Indeed, marine mammals can be regarded as an ocean safety sentinel for microplastic ingestion and plastic contaminants consumption in different baleen whales (Fossi et al., 2012, 2014, 2016; Baini et al., 2017; Lavers et al., 2019; Kuhn et al., 2020).

\subsection{Shellfish (bivalves and crustaceans)}

Bivalves seem to be the most commonly employed species in microplastic exposure investigations. Around the Minch and Orkney Islands, the lobster revealed an increased quantity of plastics and a poor uptake of plastics in the heavily damaged Clyde Sea area (Murray and Cowie, 2011; Welden and Cowie, 2016a). Additionally, the common shrimp (Crangon crangon), a decapod crustacean was also sampled from the North Sea (Devriese et al., 2015), Blue Mussels from wild and farm(Li et al., 2016; Mathalon and Hill, 2014; Van Cauwenberghe \& Janssen, 2014), pacific cup oyster from the coastal waters of Atlantic Ocean (van Cauwenberghe \& Janssen, 2014), Chinese mitten crab (Eriocheir sinensis) from coastal waters of the Baltic Sea (Wjcik-Fudalewska et al., 2016), brown mussel (Perna perna) from the Santos Estuary of Brazil (Santana et al., 2016), Manila clams (Venerupis philippinarum) from wild and farm (Davidson and Dudas, 2016) have contained by microplastics. Small bivalves with high microplastic pollution have shown similar results in Asian markets (Li et al., 2015). While this microplastic is commonly defined in the aquatic setting, it is difficult to identify or monitor the size and variety of potential sources.

\subsection{Fishes}

Microplastics have been found in various commercial fish species, both pelagic and benthic (bottomdwelling); for example, in the North Sea (Foekema et al. 2013; Rummel et al., 2016b), the North-Eastern Atlantic (Neves et al., 2015), the English Channel (Lusher et al. 2013), the Baltic Sea (Rummel et al., 2016b), the Indian Ocean (Kripa et al., 2014; Robin et al., 2020), the Indo-Pacific Ocean (Rochman et al., 2015; Jabeen et al., 2016), the Adriatic Sea (Avio et al., 2015b), the Mediterranean Sea (Bellas et al., 2016; Romeo et al., 2015; Guven et al., 2017), the North-Eastern Atlantic (Neves et al., 2015) and the Eastern Mediterranean (Guven et al., 2017). Nonetheless, for non-commercial species, the quantities observed in fish guts are often quite low (Boerger et al., 2010; Jantz et al., 2013), many of which could be prey for larger fish (Zhang et al., 2020b), between $<1-2$ particles per species who ingested microplastics. The observation that fish are globally exposed to and absorb plastic material (Koongolla et al., 2020) is confirmed by the similar findings made in the Mediterranean (Avio et al., 2015), the Arabian Sea (Sulochanan et al., 2014) and the South Atlantic (Dantas et al., 2012).

Subsequently, Fish purchased from fish markets comprised microplastics in Indonesian waters (Rochman et al., 2015) and the fish markets in Shanghai (Jabeen et al., 2016). Microplastics were also identified in the digestive systems of market-purchased freshwater fish, including Nile Tilapia 
(Oreochromis niloticus) and Nile Perch (Lates niloticus) from Lake Victoria (Tanzania). Microplastics have recently been discovered in the digestive tracts of commercially valuable species of wild fish larvae (2.9 percent of tested individuals) from the English Canal (Steer et al., 2017). While it is obvious that many commercial fish consume microplastics, nothing is known about the human consequences of doing so.

\subsection{Trophic Transfer and Bioaccumulation}

The possibility of trophic transfer and bioaccumulation is a common concern for many persistent contaminants. Bioaccumulation and trophic transfer of plastics with accompanying chemical pollutants in the aquatic ecosystem through the food web is increasing daily (Fig. 4). The initial evidence indicates the potential for trophic movement of wild-caught species from microplastics (Romeo et al., 2015; Welden and Cowie, 2016; Du et al., 2020). Benthic filter feeders, such as oysters and mussels, are well-studied for collecting plastic microfibers and other particles from the water column and transmitting them to benthic predators (Farrell and Nelson, 2013; Walkinshaw et al., 2020) and farm or wild shellfish consumers (Mathalon and Hill, 2014). Microplastic particles were also found in larger pinniped and cetacean gastrointestinal tracts, indicating a trophic transition from prey fish to top predators (Lusher et al., 2015b; Eriksson and Burton, 2003; Scherer et al., 2020). Toxins like PBDE (polybrominated diphenyl ether) have been found to be transferred from plastics to insects, amphipods, lungworms, and fish in laboratory trials (Rochman, 2016; Goswami et al., 2020).

The relative pollutant load in the environment, the plastics involved and the receiving individual depending on the situation are a main variable. Correlative data from fish (Rochman, 2016), mussels (Jang et al., 2016) and seabirds (Tanaka et al., 2013) confirms plastics' potential for causing environmental contaminants to bioaccumulate (Worm et al., 2017). As a result, the issue and question are how plastic affects fish and shellfish, as well as how it will affect seafood consumers and human health. The widespread occurrence of marine plastic debris in seafood, as well as the toxicity of chemical compounds connected with it, has raised concerns, and the weight of evidence suggests that toxins can be passed from plastic to animals (Rochman, 2015; Zhang et al., 2020).

\section{Conclusions And Future Research Perspectives}

Plastics' presence and concentration in the aquatic environment is now an undeniable fact. Microplastics have sparked considerable scientific interest and a growing body of information during the previous decade. Nonetheless, the issues surrounding fundamental questions remained unanswered.

Microplastics are a pervasive and widespread marine pollution found throughout the water column, according to a growing number of monitoring methodologies. Moreover, differences in microplastic size classifications and the lack of comparability of microplastic sampling methodologies limit our ability to compare quantitative research in order to better understand the geographical and temporal patterns of this contaminant. 
Typically, the biggest concentrations of microplastics are found along coastlines and in mid-ocean gyres, but their fates are unknown. Laboratory field trials have shown the use of microplastics in a range of marine biota, but it's unknown if ingestion of microplastics alone would be harmful to one's health (for example, mortality, morbidity, breeding success) or if such a contaminant would be regularly transmitted to the food chain. It is a significant concern that harmful chemicals are passed by microplastic intake into biota. But, the effects of MPs on freshwater organisms are much less well recognized.

We highlight several important aspects to debate based on the findings of this study in order to better understand the issue of plastic fragments or microplastics in aquatic systems:

(a) Perform further studies of plastic effects at concentrations appropriate for the environment;

(b) Carry out further laboratory studies targeting a number of most commonly developed species (fibers and fragments) and the size number $(800-1600 \mu \mathrm{m})$ of microplastics present in field biological samples;

(c) Carry out further field and laboratory experiments with freshwater species such as marine ones;

(d) Investigate the processes by which microplastics influence certain classes of species (e.g. Echinodermata, cnidaria and porifera) to help assess the importance of small crustacean studies in general to invertebrates;

(e) Consider the mechanisms by which PE affects certain classes of species other than fish and PSMPs, namely fisheries and small crustaceans;

(f) Measure the ecotoxicity of microplastics under more environmentally acceptable conditions, such as experience of multispecies and mesocosms.

(g) Public awareness campaign and strict regulation can disclose the adverse plastic effects on people and society.

Over the coming years further investigations are expected. They will be crucial to understanding the processes or processes by which plastic fragments as microplastics affect the aquatic species in order to answer realistically the specific effects of these micro and nano level contaminants on the aquatic ecosystem.

\section{Declarations}

\section{Conflicts of Interest:}

There are no conflicts of interest declared by the author. The founding sponsors had no involvement in the study's design, data collection, analysis, or interpretation, manuscript preparation, or the decision to publish the findings. 


\section{Acknowledgments:}

This research work was undertaken as part of the CGIAR Research Program on Fish Agri-Food Systems (FISH). The author acknowledges the support provided by United States Agency for International Development (USAID) for continuing this research through WorldFish's Bangladesh Country Office. The initial research was kick started during the 'Science Event on Aquaculture and Fisheries' organized by WorldFish's Bangladesh Country Office. Thanks are due to Paola Reale, Research Programs Manager and Michael Philips, Director of Aquaculture and Fisheries at WorldFish Malaysia - HQ, and Malcolm Dickson, Country Director, WorldFish's Bangladesh Country Office, for their inspiration \& encouragement.

\section{References}

Alves, V., \& Figueiredo, G. M. (2019). Microplastic in the sediments of a highly eutrophic tropical estuary. Marine pollution bulletin, 146, 326-335.

Amoatey, P., \& Baawain, M. S. (2019). Effects of pollution on freshwater aquatic organisms. Water environment research: a research publication of the Water Environment Federation, 91(10), 1272-1287.

Andrady, A. L. (2011) Microplastics in the marine environment. Marine Pollution Bulletin, 62(8). pp 15961605.

Avio, C.G., Gorbi, S. \& Regoli, F. 2015b. Experimental development of a new protocol for extraction and characterization of microplastics in fish tissues: first observations in commercial species from Adriatic Sea. Mar. Environ. Res., 111: 18-26.

Baini, M., Martellini, T., Cincinelli, A., Campani, T., Minutoli, R., Panti, C., Finoia, M.G. \& Fossi, M.C. 2017. First detection of seven phthalate esters (PAEs) as plastic tracers in superficial neustonic/planktonic samples and cetacean blubber. Anal. Methods, 9: 1512- 1520.

Basto, M. N., Nicastro, K. R., Tavares, A. I., McQuaid, C. D., Casero, M., Azevedo, F., \& Zardi, G. I. (2019). Plastic ingestion in aquatic birds in Portugal. Marine pollution bulletin, 138, 19-24.

Beaumont, N. J., Aanesen,M., Austen,M. C., Börger, T., Clark, J. R., Cole, M., Hooper, T., Lindeque, P. K., Pascoe, C., \& Wyles, K. J. (2019). Global ecological, social and economic impacts of marine plastic. Marine Pollution Bulletin, 142, 189-195.

Bellas, J., Mart.nez-Armental, J., Mart.nez-C.mara, A., Besada, V. \& Mart.nez-G.mez, C. 2016. Ingestion of microplastics by demersal fish from the Spanish Atlantic and Mediterranean coasts. Mar. Poll. Bull., 109 (1): 55-60.

Besseling, E., Foekema, E.M., van Franeker, J.A., Leopold, M.F., et al. 2015. Microplastic in a macro filter feeder: Humpback whale Megaptera novaeangliae. Mar. Pollut. Bull., 95 (1): 248-252. 
Biginagwa, F.J., Mayoma, B.S., Shashoua, Y., Syberg, K. \& Khan, F.R. 2016. First evidence of microplastics in the African Great Lakes: Recovery from Lake Victoria Nile perch and Nile tilapia. J. Great Lakes Res., 41 (1): 146-149.

Bravo Rebolledo, E.L., van Franeker, J.A., Jansen, O.E. \& Brasseur, S.M.J.M. 2013. Plastic ingestion by harbour seals (Phoca vitulina) in The Netherlands. Mar. Pollut. Bull., 67 (1-2): 200-202.

Ballent A, Corcoran PL, Madden O, Helm PA, Longstaffe FJ. Sources and sinks of microplastics in Canadian Lake Ontario nearshore, tributary and beach sediments. Marine Pollution Bulletin. 2016;110(1):383-395.

Barnes, D.K., Galgani, F., Thompson, R.C., Barlaz, M., 2009. Accumulation and fragmentation of plastic debris in global environments. Philosophical Trans. R. Soc. Biol. Sci. 364, 1985-1998.

Biginagwa, F., Mayoma, B., Shashoua, Y., Syberg, K., \& Khan, F. (2016). First evidence of microplastics in the African Great Lakes: recovery from Lake Victoria Nile perch and Nile tilapia. Journal of Great Lakes Research, 42, 1146-1149.

Blettler, M.C.M. \& Wantzen, K.M (2019). Plastic in the Thames: Threats Underestimated in Freshwater Plastic Pollution: Mini-Review. Water Air Soil Pollut, 230 (174), 1-11.

BKV, 2017. In: Vom Land ins Meer - Modell zur Erfassung landbasierter Kunststoffabf€alle.

Browne, M. A., Dissanayake, A., Galloway, T. S., Lowe, D. M., \& Thompson, R. C. (2008). Ingested microscopic plastic translocates to the circulatory system of the mussel, Mytilus edulis (L.) Environmental Science \& Technology, 42, 5026-5031.

Browne, M.A., Crump, P., Niven, S.J., Teuten, E., Tonkin, A., Galloway, T., Thompson, R., 2011. Accumulation of microplastic on shorelines woldwide: sources and sinks. Environ. Sci. Technol. 45, 9175-9179.

Browne, M.A., Underwood, A.J., Chapman, M.G., Williams, R., Thompson, R.C., van Franeker, J.A., 2015. Linking effects of anthropogenic debris to ecological impacts. Proc. Biol. Sci. 282, 20142929.

Capolupo, M., Sørensen, L., Jayasena, K., Booth, A. M., \& Fabbri, E. (2020). Chemical composition and ecotoxicity of plastic and car tire rubber leachates to aquatic organisms. Water research, 169, 115270.

Chatterjee, S. and Sharma, S. 2019. Microplastics in our oceans and marine health, Field Actions Science Reports, Special Issue 19, 54-61.

Cheshire, A. C., Adler, E., Barbière, J., Cohen, Y., et al., (2009). UNEP/IOC guidelines on survey and monitoring of marine litter. UNEP Regional Seas Reports and Studies No. 186, IOC Technical Series No. $83,120 \mathrm{p}$. 
Cole, M., Lindeque, P., Halsband, C., Galloway, T.S., 2011. Microplastics as contaminants in the marine environment: A review. Marine Pollution Bulletin 62. 2588-2597.

Crawford, C.B., Quinn, B., 2017. Microplastic Identification Techniques, Microplastic Pollutants. Elsevier, pp. 219-267.

Crew, A., Gregory-Eaves, I., \& Ricciardi, A. (2020). Distribution, abundance, and diversity of microplastics in the upper St. Lawrence River. Environmental pollution (Barking, Essex : 1987), 260, 113994.

Da Costa JP, Santos PSM, Duarte AC, Rocha-Santos T. 2016. (Nano) plastics in the environmentsources, fates and effects. Sci. Total Environ. 566-567:15-26.

Dantas, D.V., Barletta, M. \& Costa, M.F. 2012. The seasonal and spatial patterns of ingestion of polyfilament nylon fragments by estuarine drums (Sciaenidae). Environ. Sci. Pollut. Res., 19(2): 600-606.

Davidson, K. \& Dudas, S.E. 2016. Microplastic ingestion by wild and cultured Manila Clams (Venerupis philippinarum) from Baynes Sound, British Columbia. Arch. Environ. Contam. Toxicol., 71: 147-156.

Deanin RD. 1975. Additives in plastics. Environ. Health Perspect. 11:35.

Defra (2015). Review of standards for biodegradable plastic carrier bags. Department for Environment Food \& Rural Affairs, UK, 38pp.

Devriese, L.I., van der Meulen, M.D., Maes, T., Bekaert, K., Paul-Pont, I., Fr.re, L., Robbens, J. \& Vethaak A.D. 2015. Microplastic contamination in brown shrimp (Crangon crangon, Linnaeus 1758) from coastal waters of the Southern North Sea and Channel area. Mar. Pollut. Bull., 98(1): 179-187.

Dris, R., Imhof, H., Sanchez, W., Gasperi, J., Galgani, F., Tassin, B., Laforsch, C., 2015. Beyond the ocean: contamination of freshwater ecosystems with (micro-) plastic particles. Environ. Chem. 32.

Du, J., Xu, S., Zhou, Q., Li, H., Fu, L., Tang, J., Wang, Y., Peng, X., Xu, Y., \& Du, X. (2020). A review of microplastics in the aquatic environmental: distribution, transport, ecotoxicology, and toxicological mechanisms. Environmental science and pollution research international, 27 (11), 11494-11505.

Eerkes-Medrano, D.; Thompson, R.C.; Aldridge, D.C. Microplastics in freshwater systems: A review of the emerging threats, identification of knowledge gaps and prioritisation of research needs. Water Res. 2015, $75,63-82$.

Egessa, R., Nankabirwa, A., Ocaya, H., \& Pabire, W. G. (2020). Microplastic pollution in surface water of Lake Victoria. The Science of the total environment, 741, 140201.

Eriksson C, Burton H. 2003. Origins and biological accumulation of small plastic particles in fur seals from Macquarie Island. AMBIO: A J. Hum. Environ. 32:380-84. 
Eriksen, M., Mason, S., Wilson, S., Box, C., Zellers, A., Edwards, W., Farley, H., \& Amato, S. (2013).

Microplastic pollution in the surface waters of the Laurentian Great Lakes. Marine Pollution Bulletin, 77, $177-182$.

Farrell P, Nelson K. 2013. Trophic level transfer of microplastic: Mytilus edulis (L.) to Carcinus maenas (L.). Environ. Pollut. 177:1-3.

Ferreira, P., Fonte, E., Soares, M.E., Carvalho, F. \& Guilhermino, L. 2016. Effects of multi-stressors on juveniles of the marine fish Pomatoschistus microps: Gold nanoparticles, microplastics and temperature. Aquat. Toxicol., 170: 89-103.

Foekema, E.M., De Gruijter, C., Mergia, M.T., van Franeker, J.A., Murk, A.J. \& Koelmans, A.A. 2013. Plastic in North Sea fish. Environ. Sci. Technol., 47(15): 8818-8824.

Fossi, M. C., Panti, C., Guerranti, C., Coppola, D., Giannetti, M., Marsili, L. \& Minutoli, R. 2012. Are baleen whales exposed to the threat of microplastics? A case study of the Mediterranean fin whale (Balaenoptera physalus). Mar. Pollut. Bull., 64(11), 2374-2379.

Fossi, M. C., Coppola, D., Baini, M., Giannetti, M., Guerranti, C., Marsili, L., Panti, C., de Sabata, E. \& Cl., S. 2014. Large filter feeding marine organisms as indicators of microplastic in the pelagic environment: The case studies of the Mediterranean basking shark (Cetorhinus maximus) and fin whale (Balaenoptera physalus). Mar. Environ. Res., 100: 17-24.

Fossi, M.C., Marsili, L., Baini, M., Giannetti, M., et al. 2016. Fin whales and microplastics: The Mediterranean Sea and the Sea of Cortez scenarios. Environ. Pollut., 209: 68-78

Fu, Z., \& Wang, J. (2019). Current practices and future perspectives of microplastic pollution in freshwater ecosystems in China. The Science of the total environment, 691, 697-712.

Gall, S.C., Thompson, R.C., 2015. The impact of debris on marine life. Mar. Pollut. Bull. 92 (1-2), 170 e179.

Gasperi, J., Dris, R., Rocher, V., Tassin, B., 2015. Microplastics in the continental area: an emerging challenge. Norman Bull. Issue 4, $18 \mathrm{e} 19$.

GESAMP (2015). "Sources, fate and effects of microplastics in the marine environment: a global assessment" (Kershaw, P. J., ed.). (IMO/FAO/UNESCO-IOC/UNIDO/WMO/IAEA/UN/UNEP/UNDP Joint Group of Experts on the Scientific Aspects of Marine Environmental Protection). Rep. Stud. GESAMP No. $90,96 \mathrm{p}$.

GESAMP (2016). Sources, fate and effects of microplastics in the marine environment: second phase assessment part one" (Kershaw P.J. and Rochman, C. eds.) (IMO/FAO/UNESCO IOC/UNIDO/WMO/ IAEA/UN/UNEP/UNDP Joint Group of Experts on the Scientific Aspects of Marine Environmental Protection). Rep.Stud. GESAMP 
Goswami, P., Vinithkumar, N. V., \& Dharani, G. (2020). First evidence of microplastics bioaccumulation by marine organisms in the Port Blair Bay, Andaman Islands. Marine pollution bulletin, 155, 111163.

Guven, O., G.kdak, K., Jovanovic, B., \& Kıdeys, A.E. 2017. Microplastic litter composition of the Turkish territorial waters of the Mediterranean Sea, and its occurrence in the gastrointestinal tract of fish. Environ. Pollut., 223: 286-294.

Hahladakis, J.N., Velis, C.A., Weber, R., lacovidou, E., Purnell, P., 2018. An overview of chemical additives presents in plastics: Migration, release, fate, and environmental impact during their use, disposal and recycling. Journal of Hazardous materials. 344. 179-199.

Haram, L. E., Carlton, J. T., Ruiz, G. M., \& Maximenko, N. A. (2020). A Plasticene Lexicon. Marine pollution bulletin, 150, 110714 .

Imhof, H.K., Ivleva, N.P., Schmid, J., Niessner, R., Laforsch, C., 2013. Contamination of beach sediments of a subalpine lake with microplastic particles. Curr. Biol. 23 (19), R867-R868.

Ivar do Sul, J.A., Costa, M.F., 2014. The present and future of microplastic pollution in the marine environment. Environ. Pollut. 185, 352-364.

Ivleva, N.P., Wiesheu, A.C., Niessner, R., 2017. Microplastic in aquatic ecosystems. Angew. Chem. Int. Ed. 56 (7), 1720-1739.

Jabeen, K., Su, L., Li, J., Yang, D., Tong, C., Mu, J. \& Shi, H. 2016. Microplastics and mesoplastics in fish from coastal and fresh waters of China. Environ. Pollut., 221: 141-149.

Jang M, Shim WJ, Han GM, Rani M, Song YK, Hong SH. 2016. Styrofoam debris as a source of hazardous additives for marine organisms. Environ. Sci. Technol. 50:4951-60.

Klein, S., Worch, E., Knepper, T. P. (2015). Occurrence and spatial distribution of microplastics in river shore sediments of the Rhine-Main area in Germany. https://doi.org/10.1021/acs. est.5b00492.

Klein, S., Dimzon, I.K., Eubeler, J., Knepper, T.P., 2018. Freshwater Microplastics. Springer, pp. 51-67.

Koch HM, Calafat AM. 2009. Human body burdens of chemicals used in plastic manufacture. Philos.

Trans. R. Soc. B: Biol. Sci. 364:2063-78.

Koelmans, A.A., Gouin, T., Thompson, R., Wallace, N., Arthur, C., 2014. Plastics in the marine environment. Environ. Toxicol. Chem. 33, 5-10.

Koelmans, A.A., Besseling, E. \& Shim, W.J. 2015. Nanoplastics in the Aquatic Environment. Critical Review. In M. Bergmann, L. Gutow, L. \& M. Klages, eds. Marine Anthropogenic Litter, pp. 325-340. Cham, Switzerland, Springer International Publishing. 
Koongolla, J. B., Lin, L., Pan, Y. F., Yang, C. P., Sun, D. R., Liu, S., Xu, X. R., Maharana, D., Huang, J. S., \& Li, H. X. (2020). Occurrence of microplastics in gastrointestinal tracts and gills of fish from Beibu Gulf, South China Sea. Environmental pollution (Barking, Essex : 1987), 258, 113734.

Kripa, V., Nair, P. G., Dhanya, A. M., Pravitha, V. P., et al., 2014. Microplastics in the gut of anchovies caught from the mud bank area of Alappuzha, Kerala. Marine Fisheries Information Service; Technical and Extension Series (219): 27-28.

Kuhn, S., \& van Franeker, J. A. (2020). Quantitative overview of marine debris ingested by marine megafauna. Marine pollution bulletin, 151, 110858.

Lares, M., Ncibi, M. C., Sillanpaa, M. \& Sillanpaa, M. (2018). Occurrence, identification and removal of microplastic particles and fibers in conventional activated sludge process and advanced MBR technology. Water Research, 133, 236-246.

Lavers, J. L., Stivaktakis, G., Hutton, I., \& Bond, A. L. (2019). Detection of ultrafine plastics ingested by seabirds using tissue digestion. Marine pollution bulletin, 142, 470-474.

Lebreton, L.C.M., Zwet, J. Van Der, Damsteeg, J., Slat, B., Andrady, A., Reisser, J., 2017. River plastic emissions to the world's oceans. Nat. Commun. 8, 15611. https:// doi.org/10.1038/ncomms15611.

Li, J., Yang, D., Li, L., Jabeen, K. \& Shi, H. 2015. Microplastics in commercial bivalves from China. Environ. Pollut., 207: 190-195.

Li, J., Qu, X., Su, L., Zhang, W., Yang, D., Kolandhasamy, P., Li, D. \& Shi, H. 2016. Microplastics in mussels along the coastal waters of China. Environ. Pollut., 214: 177-184.

Li, J., Liu, H., Chen J.P. 2018. Microplastics in freshwater systems: A review on occurrence, environmental effects, and methods for microplastics detection. Water Research. 137: 362-374.

Li, C., Busquets, R., \& Campos, L. C. (2020). Assessment of microplastics in freshwater systems: A review. The Science of the total environment, 707, 135578.

Lithner D, LarssonA,DaveG. 2011. Environmental and health hazard ranking and assessment of plastic polymers based on chemical composition. Sci. Total Environ. 409:3309-24.

Liu, P., Zhan, X., Wu, X., Li, J., Wang, H., \& Gao, S. (2020a). Effect of weathering on environmental behavior of microplastics: Properties, sorption and potential risks. Chemosphere, 242, 125193.

Liu, Y., He, Y., Zhang, J., Cai, C., Breider, F., Tao, S., \& Liu, W. (2020b). Distribution, partitioning behavior, and ecological risk assessment of phthalate esters in sediment particle-pore water systems from the main stream of the Haihe River, Northern China. The Science of the total environment, 745, 141131. 
Lobelle, D. and Cunliffe, M. 2011. Early microbial biofilm formation on marine plastic debris. Mar. Pollut. Bull., 62(1): 197-200.

Lusher AL, Hernandez-Milian G, O'Brien J, Berrow S, O'Connor I, Officer R. 2015b. Microplastic and macroplastic ingestion by a deep diving, oceanic cetacean: the True's beaked whale Mesoplodon mirus. Environ. Pollut. 199:185-91.

Lusher, A.L., McHugh, M. \& Thompson, R.C. 2013. Occurrence of microplastics in the gastrointestinal tract of pelagic and demersal fish from the English Channel. Mar. Pollut. Bull., 67(1): 94-99.

Lusher, A. 2015. Microplastics in the marine environment: distribution, interactions and effects. In M. Bergmann, L. Gutow, L. \& M. Klages, eds. Marine Anthropogenic Litter, pp. 245-307. Cham, Switzerland, Springer International Publishing.

Lusher, A.L., Hernandez-Milian, G., O’Brien, J., Berrow, S., O'Connor, I. \& Officer, R. 2015a. Microplastic and macroplastic ingestion by a deep diving, oceanic cetacean: The True's beaked whale Mesoplodon mirus. Environ. Pollut., 199: 185-191.

Lusher, A.L.; Hollman, P.C.H.; Mendoza-Hill, J.J. 2017a. Microplastics in fisheries and aquaculture: status of knowledge on their occurrence and implications for aquatic organisms and food safety. FAO Fisheries and Aquaculture Technical Paper. No. 615. Rome, Italy.

Lusher, A., Welden, N., Sobral, P. \& Cole, M. 2017b. Sampling, isolating and identifying microplastics ingested by fish and invertebrates. Anal. Methods, 9: 1346-1360.

Ma, H., Pu, S., Liu, S., Bai, Y., Mandal, S., \& Xing, B. (2020). Microplastics in aquatic environments: Toxicity to trigger ecological consequences. Environmental pollution (Barking, Essex : 1987), 261, 114089.

Martins, I., Bessa, F., Gonçalves, A., Gago, J., \& Libralato, S. (2019). MODELPlastics workshop - Modelling Ocean Plastic Litter in a Changing Climate: Gaps and future directions. Marine pollution bulletin, 146, 2225.

Masia, P., Sol, D., Ardura, A., Laca, A., Borrell, Y. J., Dopico, E., Laca, A., Machado-Schiaffino, G., Díaz, M., \& Garcia-Vazquez, E. (2020). Bioremediation as a promising strategy for microplastics removal in wastewater treatment plants. Marine pollution bulletin, 156, 111252.

Mataji, A., Taleshi, M. S., \& Balimoghaddas, E. (2020). Distribution and Characterization of Microplastics in Surface Waters and the Southern Caspian Sea Coasts Sediments. Archives of environmental contamination and toxicology, 78(1), 86-93.

Mathalon, A. \& Hill, P. 2014. Microplastic fibers in the intertidal ecosystem surrounding Halifax Harbor, Nova Scotia. Mar. Pollut. Bull., 81(1): 69-79. 
Morritt, D., Stefanoudis, P. V., Pearce, D., Crimmen, A., \& Clark, P. F. (2014). Plastic in the Thames: a river runs through it. Marine Pollution Bulletin, 78, 196-200.

Murray, F. \& Cowie, P.R. 2011. Plastic contamination in the decapod crustacean Nephrops norvegicus (Linnaeus, 1758). Mar. Pollut. Bull., 62(6): 1207-1217.

Nerland, I.L., Halsband, C., Allan, I. \& Thomas, K.V. (2014). Microplastics in marine environments: Occurrence, distribution and effects. Norwegian Institute for Water Research, Report No. 6754-2014: 71 pp.

Neves, D., Sobral, P., Ferreira, J.L. \& Pereira, T. 2015. Ingestion of microplastics by commercial fish off the Portuguese coast. Mar. Pollut. Bull., 101 (1): 119-126.

Noik, V. J., \& Tuah, P. M. (2015). A first survey on the abundance of plastics fragments and particles on two sandy beaches in Kuching, Sarawak, Malaysia. IOP Conference Series: Materials Science and Engineering, 78, 012035. https://doi. org/10.1088/1757-899X/78/1/012035.

Prata, J. C., da Costa, J. P., Lopes, I., Duarte, A. C., \& Rocha-Santos, T. (2020). Environmental status of (micro)plastics contamination in Portugal. Ecotoxicology and environmental safety, 200, 110753.

Pathak, V.M., Navneet, 2017. Review on the current status of polymer degradation: a microbial approach. Bioresour. Bioprocess. 4, 15.

Peng, J., Wang, J., Cai, L., 2017. Current understanding of microplastics in the environment: occurrence, fate, risks, and what we should do. Integr. Environ. Assess. Manag. 13, 476-482.

Pereao, O., Opeolu, B., \& Fatoki, O. (2020). Microplastics in aquatic environment: characterization, ecotoxicological effect, implications for ecosystems and developments in South Africa. Environmental science and pollution research international, 27(18), 22271-22291.

Plastics Europe, 2008. The compelling facts about plastics 2007, an analysis of plastics production, demand and recovery for 2007 in Europe. Plastics Europe, Brussels, Belgium.

PlasticsEurope (2015). Plastics - the facts 2014/2015. An Analysis of European plastics production, demand and waste data. PlasticsEurope, Brussels, Belgium: 30 pp.

PlasticsEurope, 2016. Plastics - the Facts 2016. An Analysis of European Plastics Production, Demand and Waste Data. Available online at: http://www. plasticseurope.org/Document/plastics-the-facts-201615787.aspx?FolID.2.

Qi, R., Jones, D. L., Li, Z., Liu, Q., \& Yan, C. (2020). Behavior of microplastics and plastic film residues in the soil environment: A critical review. The Science of the total environment, 703, 134722. 
Robin, R. S., Karthik, R., Purvaja, R., Ganguly, D., Anandavelu, I., Mugilarasan, M., \& Ramesh, R. (2020). Holistic assessment of microplastics in various coastal environmental matrices, southwest coast of India. The Science of the total environment, 703, 134947.

Rochman, C. M., Hoh, E., Kurobe, T., \& Teh, S. J. (2013a). Ingested plastic transfers hazardous chemicals to fish and induces hepatic stress. Scientific Reports, 3, 3263

Rochman CM, Browne MA, Halpern BS, Hentschel BT, Hoh E, et al. 2013b. Classify plastic waste as hazardous. Nature 494:169-171.

Rochman CM. 2015. The complex mixture, fate and toxicity of chemicals associated with plastic debris in the marine environment. See Ref. 109, pp. 117-40.

Rochman, C.M., Tahir, A., Williams, S.L., Baxa, D.V., Lam, R., Miller, J.T., Teh, F.C., Werorilangi, S. \& Teh, S.J. 2015. Anthropogenic debris in seafood: Plastic debris and fibers from textiles in fish and bivalves sold for human consumption. Sci. Rep., 5: 14340. doi:10.1038/srep14340.

Rochman CM. 2016. The role of plastic debris as another source of hazardous chemicals in lower-trophic level organisms. In The Handbook of Environmental Chemistry, ed. D Barcel ' o, AG Kostianoy, pp. 1-15. New York: Springer.

Rochman, C.M. Microplastics research-From sink to source. Science 2018, 360, 28-29.

Roman, L., Paterson, H., Townsend, K. A., Wilcox, C., Hardesty, B. D., \& Hindell, M. A. (2019). Size of marine debris items ingested and retained by petrels. Marine pollution bulletin, 142, 569-575.

Romeo, T., Pietro, B., Ped., C., Consoli, P., Andaloro, F. \& Fossi, M.C. 2015. First evidence of presence of plastic debris in stomach of large pelagic fish in the Mediterranean Sea. Mar. Pollut. Bull., 95(1): 358-361.

Rosenkranz, P., Chaudhry, Q., Stone, V., \& Fernandes, T. F. (2009). A comparison of nanoparticle and fine particle uptake by Daphnia magna. Environmental Toxicology and Chemistry, 28, 2142-2149.

Rummel, C.D., L.der, M.G., Fricke, N.F., Lang, T., Griebeler, E.M., Janke, M. \& Gerdts, G. 2016b. Plastic ingestion by pelagic and demersal fish from the North Sea and Baltic Sea. Mar. Pollut. Bull., 102(1): 134141.

Saeed, T., Al-Jandal, N., Al-Mutairi, A., \& Taqi, H. (2020). Microplastics in Kuwait marine environment: Results of first survey. Marine pollution bulletin, 152, 110880.

Sanchez, W., Bender, C., \& Porcher, J. M. (2014). Wild gudgeons (Gobio gobio) from French rivers are contaminated by microplastics: preliminary study and first evidence. Environmental Research, 128, 98100. 
Santana, M.F.M., Ascer, L.G., Cust.dio, M.R., Moreira, F.T. \& Turra, A. 2016. Microplastic contamination in natural mussel beds from a Brazilian urbanized coastal region: Rapid evaluation through bioassessment. Mar. Pollut. Bull., 106(1): 183-189.

Scherer, C., Wolf, R., Völker, J., Stock, F., Brennhold, N., Reifferscheid, G., \& Wagner, M. (2020). Toxicity of microplastics and natural particles in the freshwater dipteran Chironomus riparius: Same same but different?. The Science of the total environment, 711, 134604.

Shafiq M., Qadir A., Hussain C.M. (2019) Microplastics as Contaminant in Freshwater Ecosystem: A Modern Environmental Issue. In: Hussain C. (eds) Handbook of Environmental Materials Management. Springer, Cham. pp 1-24.

Song, Y.K., Hong, S.H., Jang, M., Han, G.M., Jung, S.W., Shim, W.J., 2017. Combined effects of UV exposure duration and mechanical abrasion on microplastic fragmentation by polymer type. Environ. Sci. Technol. 51, 4368-4376.

Steer, M., Cole, M., Thompson, R.C. \& Lindeque, P.K. 2017. Microplastic ingestion in fish larvae in the western English Channel. Environ. Pollut., 226: 250-259.

Stoiev, S. B., Turra, A. 2016. Small-scale temporal and spatial variability in the abundance of plastic pellets on sandy beaches: Methodological considerations for estimating the input of microplastics. Marine Pollution Bulletin 102, 114-121.

Sulochanan, B., Bhat, G.S., Lavanya, S., Dineshbabu, A.P. \& Kaladharan, P. 2014. A preliminary assessment of ecosystem process and marine litter in the beaches of Mangalore. Indian J. Geo-Mar. Sci., 43 (9): 1764-1769.

Tanaka K, Takada H, Yamashita R, Mizukawa K, Fukuwaka M-A, Watanuki Y. 2013. Accumulation of plastic-derived chemicals in tissues of seabirds ingesting marine plastics. Mar. Pollut. Bull. 69:219-22.

Taylor, M.L., Gwinnett, C., Robinson, L.F. \& Woodall, L.C. 2016. Plastic microfibre ingestion by deep-sea organisms. Sci. Rep., 6: 33997. doi: 10.1038/srep33997.

Teuten, E. L., Saquing, J. M., Knappe, D. R., Barlaz, M. A., et al., (2009). Transport and release of chemicals from plastics to the environment and to wildlife. Philosophical Transactions of the Royal Society of London. Series B, Biological Sciences, 364, 2027-2045.

Uddin, S., Fowler, S. W., \& Saeed, T. (2020). Microplastic particles in the Persian/Arabian Gulf - A review on sampling and identification. Marine pollution bulletin, 154, 111100.

UNEP (2016). Marine plastic debris and microplastics - Global lessons and research to inspire action and guide policy change. United Nations Environment Programme, Nairobi. 
Van Cauwenberghe, L. \& Janssen, C.R. 2014. Microplastics in bivalves cultured for human consumption. Environ. Pollut., 193: 65-70.

Vandermeersch G, Van Cauwenberghe L, Janssen CR, Marques A, Granby K, et al. (2015) A critical Review on Microplastic quantification in aquatic organisms. Envt Res 143: 46-55.

Van Franeker, J. A., Blaize, C., Danielsen, J., Fairclough, K., et al., 2011. Monitoring plastic ingestion by the northern fulmar Fulmarus glacialis in the North Sea. Environ. Pollut., 159(10): 2609-2615.

Vince, J., Hardesty, B.D., 2017. Plastic pollution challenges in marine and coastal environments: from local to global governance. Restor. Ecol. 25, 123-128.

Wagner, M., Scherer, C., Alvarez-Munoz, D., Brennholt, N., Bourrain, X., et al. (2014). Microplastics in freshwater ecosystems: what we know and what we need to know. Environmental Sciences Europe, 26, 12.

Wagner, M., S. Lambert (eds.), 2018. Freshwater Microplastics, Hdb Env Chem 58, DOI 10.1007/978-3319-61615-5_14.

Walkinshaw, C., Lindeque, P. K., Thompson, R., Tolhurst, T., \& Cole, M. (2020). Microplastics and seafood: lower trophic organisms at highest risk of contamination. Ecotoxicology and environmental safety, 190, 110066.

Wang, W., Ndungu, A.W., Li, Z., Wang, J., 2017. Microplastics pollution in inland freshwaters of China: a case study in urban surface waters of Wuhan, China. Sci. Total Environ. 575, 1369-1374.

Wang, F., Wang, B., Duan, L., Zhang, Y., Zhou, Y., Sui, Q., Xu, D., Qu, H., \& Yu, G. (2020a). Occurrence and distribution of microplastics in domestic, industrial, agricultural and aquacultural wastewater sources: $A$ case study in Changzhou, China. Water research, 182, 115956.

Wang, W., Ge, J., \& Yu, X. (2020b). Bioavailability and toxicity of microplastics to fish species: A review. Ecotoxicology and environmental safety, 189, 109913.

Welden, N.A. \& Cowie, P.R. 2016. Environment and gut morphology influence microplastic retention in langoustine, Nephrops norvegicus. Environ. Pollut., 214: 859-865.

Wojcik-Fudalewska, D., Normant-Saremba, M. \& Anast.cio, P. 2016. Occurrence of plastic debris in the stomach of the invasive crab Eriocheir sinensis. Mar. Pollut. Bull., 113 (1-2): 306-311.

World Economic Forum, Ellen MacArthur Foundation, McKinsey \& Company, The New Plastics Economy Rethinking the Future of Plastics, 2016. Available from: http://www.ellenmacarthurfoundation.org/publications. 
Wright, S.L., Rowe, D., Thompson, R.C. \& Galloway, T.S. 2013. Microplastic ingestion decreases energy reserves in marine worms. Curr. Biol., 23(23): R1031-R1033.

Wright, S. L., Thompson R. C., \& Galloway, T. S. 2013. The physical impacts of 252 microplastics on marine organisms: a review. Environ. Poll. 178, 483-492.

Xu, C., Zhang, B., Gu, C., Shen, C., Yin, S., Aamir, M., \& Li, F. (2020). Are we underestimating the sources of microplastic pollution in terrestrial environment?. Journal of hazardous materials, 400, 123228.

Yu, Q., Hu, X., Yang, B., Zhang, G., Wang, J., \& Ling, W. (2020). Distribution, abundance and risks of microplastics in the environment. Chemosphere, 249, 126059.

Zhang, R., Silic, M. R., Schaber, A., Wasel, O., Freeman, J. L., \& Sepúlveda, M. S. (2020a). Exposure route affects the distribution and toxicity of polystyrene nanoplastics in zebrafish. The Science of the total environment, 724, 138065 .

Zhang, C., Wang, S., Pan, Z., Sun, D., Xie, S., Zhou, A., Wang, J., \& Zou, J. (2020b). Occurrence and distribution of microplastics in commercial fishes from estuarine areas of Guangdong, South China. Chemosphere, 260, 127656.

\section{Figures}

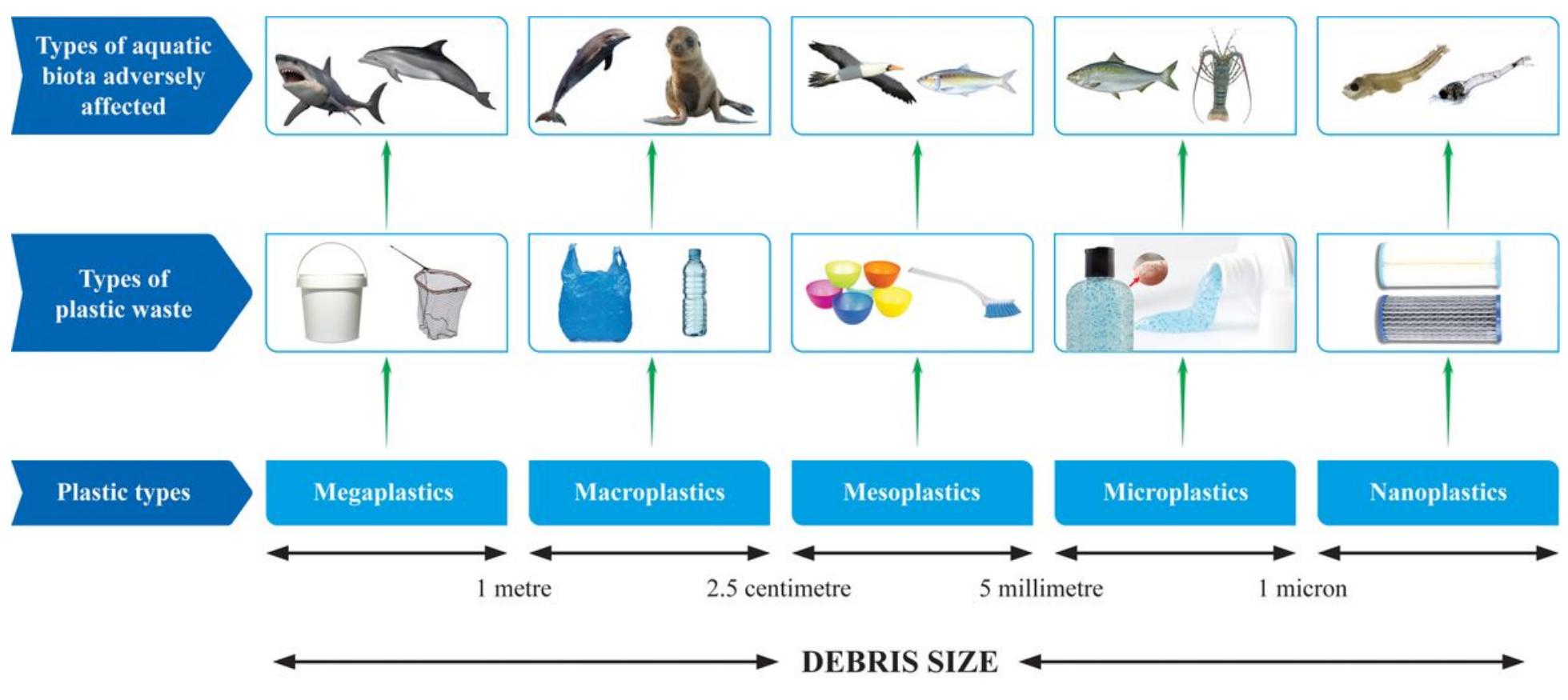

Figure 1

Different forms of plastics and their effects on aquatic life 


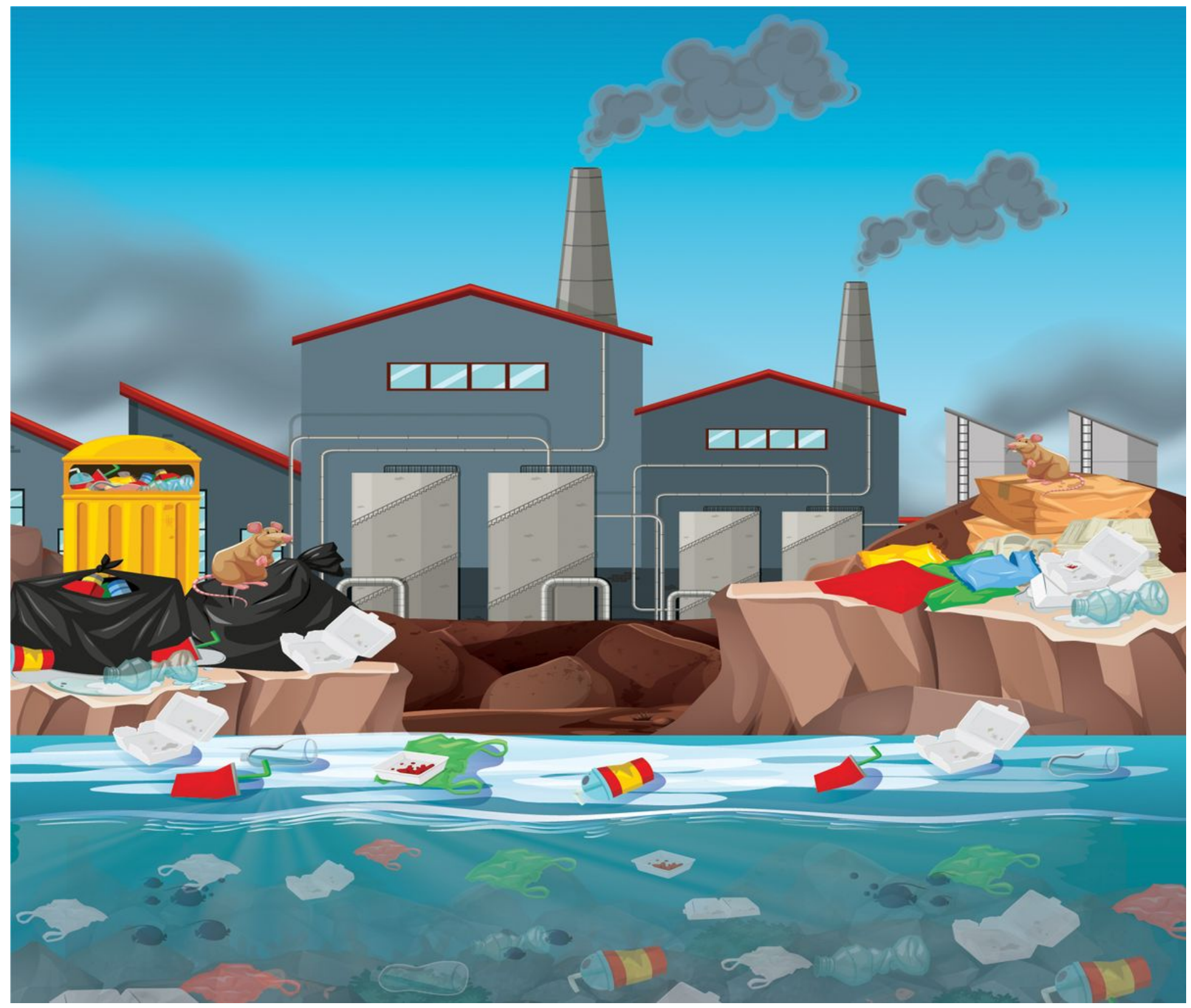

Figure 2

Plastics can enter the environment through industrial manufacturing or uncontrolled anthropogenic processes 


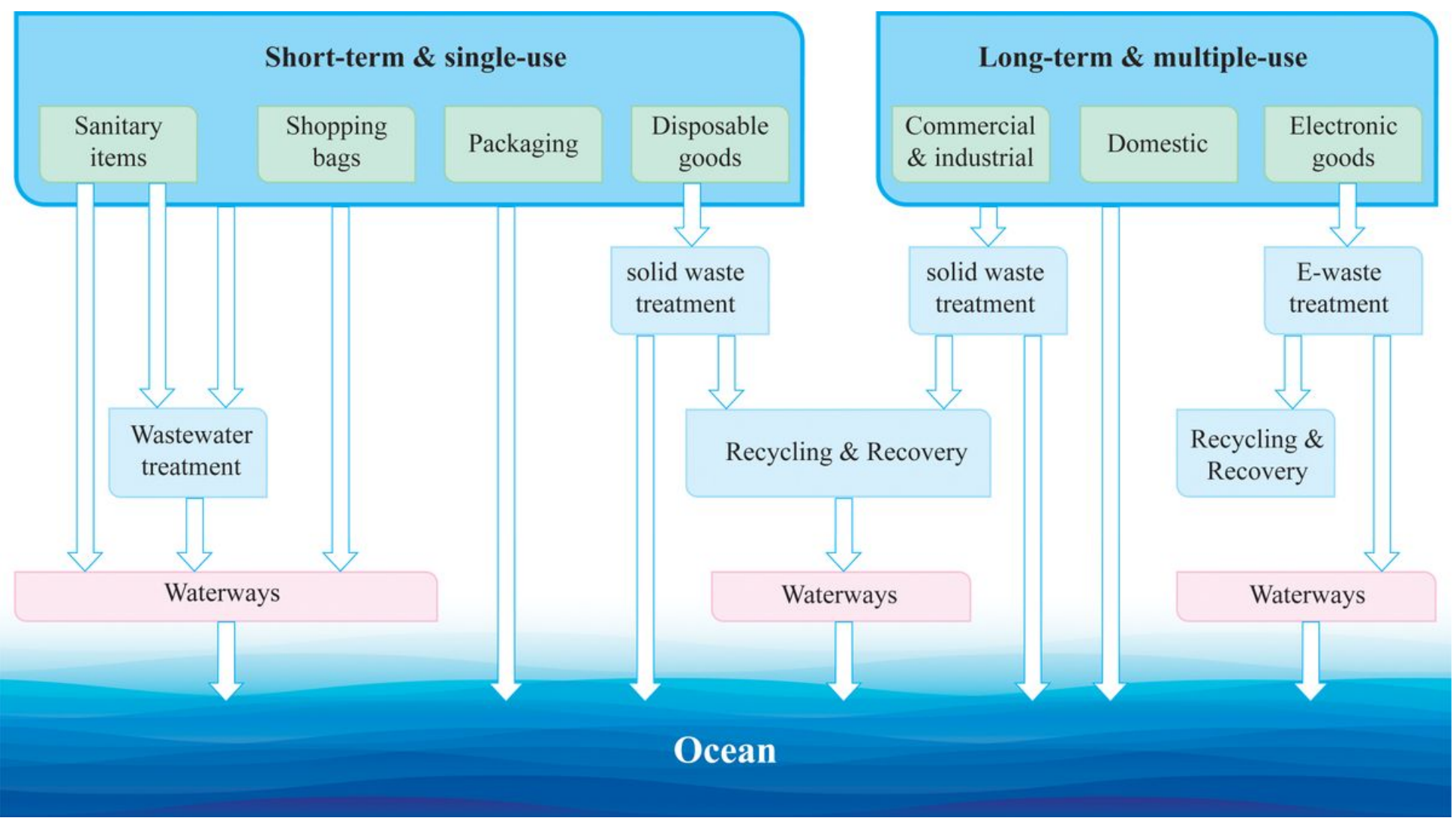

\section{Figure 3}

Plastic pollution uptake and probable trophic transmission in aquatic food webs
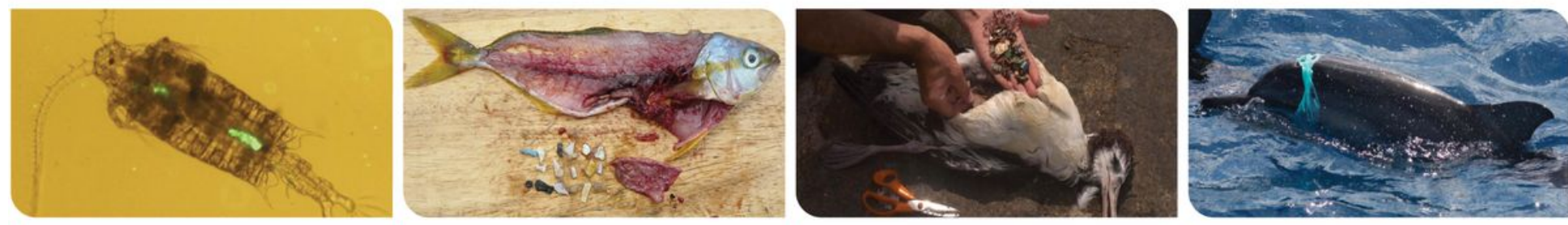

Nanoplastics $(<1 \mu \mathrm{m})$

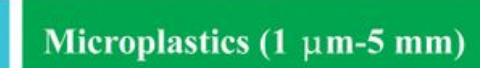

Mesoplastics (5-200 mm)

Mesoplastics $(>200 \mathrm{~mm})$
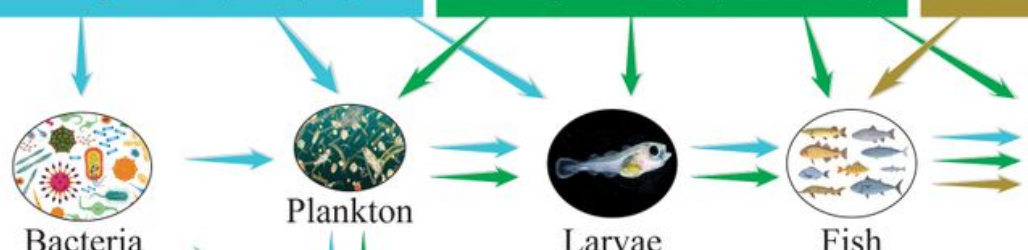

Bacteria
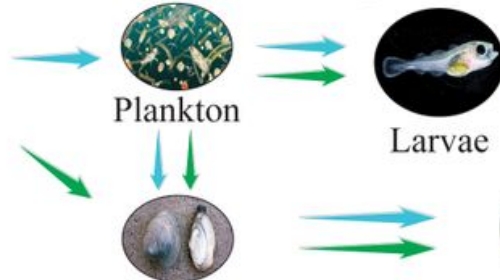

Larvae

Fish
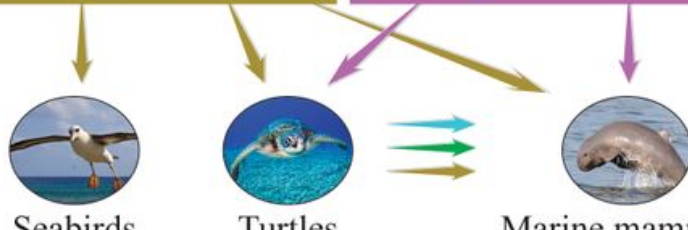

Marine mammals<smiles>c1ccccc1</smiles>

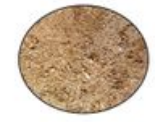

Filter feeders
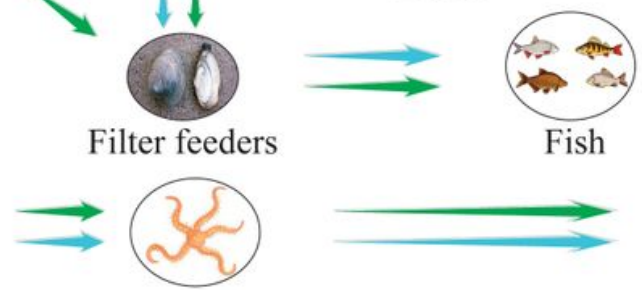

Deposit feeders
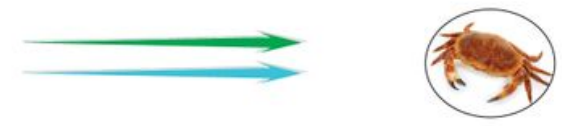

Benthic predators
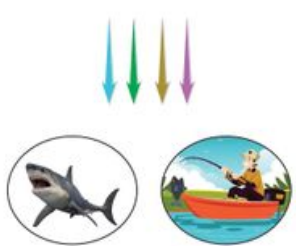

Top predators

\section{Figure 4}


Plastic pollution uptake and probable trophic transmission in aquatic food webs 